\title{
PENGARUH METODE EKSPERIMEN TERHADAP KEMAMPUAN SAINS ANAK KELOMPOK B TK TUNAS HARAPAN 1 TUNGGUNJAGIR KECAMATAN MANTUP KABUPATEN LAMONGAN
}

\author{
Lina Eka Retnaningsih \\ Program Studi PIAUD, Fakultas Agama Islam, Universitas Islam Lamongan \\ Jl.Veteran No. 53 A Lamongan 62213 \\ Telp. 0322-324706/0856-4803-0635 \\ E-mail: linaekasaja@yahoo.co.id
}

\begin{abstract}
The purpose of this study is to know the science ability of group B children of Tunas Harapan kindergarten 1 Tunggunjagir Mantup Lamongan before applying experimental method, and to know the science ability of group $B$ children of Tunas Harapan kindergarten 1 Tunggunjagir Mantup Lamongan after applying experimental method. This study uses pre-experimental design with onegroup pretest-posttest design. Data collection technique uses observation. The subjects of this study were 16 children. The validity instrument uses the validity construction test, while its reliability uses the observation reliability test with the formula presented by Fernandes. Data obtained in the field were analyzed by using data analysis technique of wilcoxon match pairs test. From the calculation results it is obtained the average scores of pre-test results amounted to 20.8 and the average scores of post-test results amounted to 26.8 with Tcount $\leq$ Ttable $(0 \leq$ 21). Thus, it could be concluded that the alternative hypothesis (Ha) is accepted and the null hypothesis $(\mathrm{Ho})$ is rejected. That means the research hypothesis that there is influence of experimental methods on the science skills of group B children of Tunas Harapan Kindergarten 1 Tunggunjagir district Mantup Lamongan Regency is accepted.
\end{abstract}

Keywords: Science Ability, Experimental Method

\section{Pendahuluan}

Masa anak-anak merupakan masa dimana individu sedang mengalami suatu proses pertumbuhan dan perkembangan yang pesat dan mendasar, baik secara fisik maupun mental bagi kehidupan selanjutnya. Hal ini berimplikasi pada pendidikan pada masa usia dini yang kemudian menjadi proses pendidikan yang fundamental. Pendidikan pada masa usia dini sangat penting untuk memberikan kerangka dasar dalam terbentuk dan berkembangnya dasardasar pengetahuan, sikap, dan kemampuan pada anak. Hal ini sejalan dengan pendapat Montessori yang menyatakan bahwa rentang usia lahir sampai 6 tahun anak mengalami masa keemasan (the golden age years) yang merupakan masa ketika anak mulai mampu untuk menerima berbagai stimulasi dan berbagai upaya pendidikan dari lingkungannya baik yang disengaja ,maupun yang tidak disengaja. ${ }^{1}$

Anak-anak secara naluriah aktif bergerak, dan dengan kecenderungan itu mereka mengkontribusi kemampuan dan belajarnya sendiri sebagai akibat dari upayanya memaknai

\footnotetext{
${ }^{1}$ Yuliani Nurani Sujiono, Konsep Dasar Pendidikan Anak Usia Dini (Jakarta: Indeks, 2009), 2.
} 
pengalaman kesehariannya di rumah, di tempat bermain, di sekolah, dan di lingkungan masyarakatnya yang lebih luas. Anak-anak belajar secara aktif dari observasi terhadap lingkungan dan partisipasi dengan anak-anak lain dan orang dekat yang dipercayainya termasuk orang tua, pengasuh, dan guru. Anak-anak sejak usia dini dengan aktif membangun berbagai pemahaman dari pengalamannya, dan pemahaman ini dijembatani dan erat berkaitan serta menyatu dengan konteks sosial budaya dan lingkungannya. ${ }^{2}$

Ada lima aspek perkembangan yang dapat dikembangkan pada diri anak usia dini. Salah satu aspek yang penting untuk dikembangkan adalah aspek kognitif. Pengembangan aspek bidang kognitif dalam hal ini pengetahuan umum dan sains memliki peranan penting dalam membantu meletakkan dasar kemampuan dan pembentukan sumber daya manusia yang diharapkan.

Menurut Jamaris, Ilmu Pengetahuan Alam (Sains) pada hakikatnya dapat ditanamkan pada anak sedini mungkin. Selain itu pemahaman anak mengenai sains akan lebih berfungsi jika dikembangkan dengan seksama melalui kegiatan di Taman Kanak-kanak. ${ }^{3}$

Berdasarkan hasil pengamatan awal yang dilakukan pada kelompok B TK Tunas Harapan 1 Tunggunjagir kecamatan Mantup kabupaten Lamongan ditemukan bahwa pembelajaran sains masih jarang dikembangkan. Kemampuan kognitif anak masih kurang dalam pengetahuan umum mengenai konsep sains sederhana. Konsep sains yang dikenalkan bukan diberikan melalui kegiatan praktek langsung tetapi guru hanya menjelaskan tentang konsep sains sederhana, seperti proses pertumbuhan tanaman. Pembelajaran yang berpusat pada guru mengakibatkan anak kurang memahami penjelasan guru mengenai konsep sains tersebut, sehingga kemampuan sains anak cenderung rendah.

Salah satu alternatif yang akan digunakan peneliti untuk pembelajaran sains yaitu dengan metode eksperimen, di mana anak akan bereksplorasi dengan lingkungan dengan melakukan percobaan-percobaan sains yang tentunya dengan bimbingan guru. Metode eksperimen terbimbing mengajak anak untuk aktif mengalami proses dan membuktikan sendiri tentang apa yang sedang dipelajarinya sehingga anak mampu membangun konsep mengenai sains dan mampu berpikir kritis, sistematis dan logis dengan melakukannya sendiri. Berdasarkan hasil penelitian sebelumnya pula, yaitu Studi Eksperimen di TK KPAD Gegerkalong Bandung pada tahun 2011 yang menunjukkan bahwa metode eksperimen dapat mempengaruhi keterampilan proses sains anak secara signifikan.

Penerapan kegiatan sains di TK seyogyanya lebih mementingkan proses daripada hasil, tetapi kenyataan di lapangan menunjukkan bahwa kegiatan sains lebih menekankan pada hasil.Praktek sains di lapangan masih menggunakan metode-metode konvensional di mana guru menggunakan metode berceramah, diskusi, yang membuat anak banyak mendengar, duduk, dan diam, padahal hakikat sains adalah memberikan pengalaman yang menantang sehingga memfasilitasi rasa ingin tahu anak dengan menyuguhkan pembelajaran yang variatif, menyenangkan, menantang anak untuk mengobservasi dan mengeksplorasi berbagai macam obyek fisik dan alam, serta kejadian-kejadian yang ada di lingkungan anak. Berdasarkan latar belakang pemikiran di atas dan permasalahan yang ditemukan di lapangan, maka penelitian

\footnotetext{
${ }^{2}$ Ali Nugraha, Pengembangan Pembelajaran Sains Pada Anak Usia Dini (Jakarta: Depdiknas, 2005), 89.

${ }^{3}$ Dwi Yulianti, Bermain Sambil Belajar Sains di Taman Kanak-kanak (Jakarta: Indeks, 2010), 24.
} 
ini terarah pada pengujian pengaruh penggunaan metode eksperimen terhadap kemampuan sains pada kelompok B di TK Tunas Harapan 1 Tunggunjagir, Lamongan.

Pentingnya tahun-tahun awal kehidupan seseorang harus disadari karena pada pada usia dinilah otak individu berkembang pesat bahkan penelitian yang yang dapat dipercaya menyatakan bahwa kemampuannya mencapai hingga lebih dari $50 \% .{ }^{4}$ Dengan bermain anak mempunyai kesempatan untuk bereksplorasi, menemukan, mengekspresikan, berkreasi, dan belajar secara menyenangkan. Karena Taman Kanak-kanak merupakan awal pendidikan di sekolah, oleh karena itu Taman Kanak-kanak perlu menciptakan situasi pendidikan yang dapat memberikan rasa aman, nyaman dan menyenangkan melalui penerapan metode pembelajaran yang sesuai dengan karakteristik anak.

Usia dini adalah fase fundametal bagi kemampuan individu yang disebut juga golden age atau usia emas. Pengalaman-pengalaman yang dijalani anak mungkin akan membentuk pengalaman yang akan dibawa seumur hidupnya. Implikasinya pada bidang pendidikan usia dini adalah diperlukan langkah yang tepat untuk membekali anak sejak usia tersebut. Salah satu langkah yang signifikan dan strategis untuk dapat memberikan pembekalan yang optimal pada anak adalah didahului dengan memahami karakteristik dan tujuan pendidikan dan pembelajaran yang akan diterapkan pada anak usia dini, termasuk dalam bidang pengembangan pembelajaran sains untuk anak. ${ }^{5}$ Pelaksanaan pembelajaran sains harus disesuaikan dengan tahap-tahap kemampuan anak. Dalam pelaksanaan proses belajar mengajar sains di Taman Kanak-kanak, guru harus memahami dan menguasai metode pembelajaran sains yang digunakan. Dengan menguasai metode pembelajaran sains, diharapkan tujuan pendidikan di Taman Kanak-kanak dapat mengembangkan kemampuan fisik, kognisi, bahasa, sosial-emosi, konsep diri, disiplin, kemandirian, seni, moral, dan nilainilai agama dapat tercapai secara terpadu dan optimal. ${ }^{6}$

Menurut Nasrudin, ${ }^{7}$ sains adalah suatu pengetahuan teoritis yang diperoleh atau disusun dengan cara yang khas, yaitu melakukan pengamatan, percobaan, penyimpulan, penyusunan teori, dan demikian seterusnya kait-mengkait antara cara yang satu dengan cara yang lain. Pernyataan tersebut memiliki makna bahwa penyusunan pengetahuan tersebut dilakukan secara sistematis dan saling berkesinambungan agar diperoleh suatu pengetahuan yang akurat dan bermakna. Kegiatan pembelajaran pada anak usia dini pada hakikatnya adalah pengembangan kurikulum secara konkret berupa seperangkat rencana yang berisi sejumlah pengalaman belajar melalui bermain yang diberikan kepada anak berdasarkan potensi dan tugas kemampuan yang harus dikuasainya dalam rangka pencapaian kompetensi yang harus dimiliki oleh anak.

Sejalan dengan pendapat di atas, Sujiono juga menyatakan bahwa secara umum kegiatan sains dalam pendidikan anak usia dini membantu anak agar mampu secara aktif mencari informasi tentang apa yang ada disekitarnya, sebab melalui eksplorasi di bidang sains anak mencoba memahami dunianya dengan cara pengamatan, penyelidikan dan percobaan. ${ }^{8}$

\footnotetext{
${ }^{4}$ Ali Nugraha, Pengembangan Pembelajaran Sains Pada Anak Usia Dini (Jakarta: Depdiknas, 2005$), 23$.

${ }^{5}$ Ibid., 23.

${ }^{6}$ Dwi Yulianti, Bermain Sambil Belajar Sains di Taman Kanak-kanak (Jakarta: Indeks, 2010), 26.

${ }^{7}$ Nasrudin dalam Yuliani Nurani Sujiono, Konsep Dasar Pendidikan Anak Usia Dini (Jakarta: Indeks, 2009), 138.

${ }^{8}$ Yuliani Nurani Sujiono, Metode Pengembangan Kognitif (Jakarta: Universitas Terbuka, 2004), 123.
} 
Lebih ringkas Yulianti menjelaskan, kemampuan sains yang dapat dikembangkan untuk anak usia dini adalah: ${ }^{9}$

1. Mengamati, anak diajak untuk mengamati fenomena alam yang terjadi di lingkungan anak itu sendiri.

2. Mengelompokkan, anak diminta untuk menggolongkan benda-benda sesuai dengan kategorinya.

3. Memperkirakan, anak diminta untuk memperkirakan apa yang terjadi.

4. Menghitung, anak didorong untuk menghitung benda-benda yang ada di sekeliling dan mengenalkan bentuk kepadanya.

Sejalan dengan pendapat di atas, Sujiono menyebutkan lebih rinci mengenai kemampuan sains yang dikembangkan untuk anak adalah: Observasi, Klasifikasi, Perkiraan, Prediksi, Eksperimen, Komunikasi. ${ }^{10}$

Selain itu, dalam mengembangkan kemampuan sains anak perlu diperhatikan ramburambu pembelajaran sains anak usia dini yang dikemukakan oleh Suyanto ${ }^{11}$ antara lain bersifat konkret, hubungan sebab akibat terjadi secara langsung, memungkinkan anak untuk melakukan eksplorasi, memungkinkan anak mengkontruksi pengetahuannya sendiri, memungkinkan anak menjawab pertanyaan apa daripada mengapa, lebih menekankan proses daripada produk, memungkinkan anak menggunakan bahasa dan matematika, menyajikan kegiatan yang menarik (the wonder of science).

Banyak topik yang bisa dipilih dalam pembelajaran sains untuk anak usia dini, salah satunya adalah kegiatan percobaan larut tidak larut. Mengenalkan anak dengan air merupakan salah satu kegiatan yang dapat membuat anak mengenal alam dan lingkungannya. Air termasuk zat yang sering ditemui anak-anak dalam kehidupannya. Ketika anak mandi, minum, berenang, memancing, berlayar, menyelam serta bermain dengan air hujan, anak akan berinteraksi dengan air.

Bermain dengan air terlihat menarik bagi semua anak. Selain menarik hal tersebut juga dapat menahan perhatian anak dalam jangka waktu yang lama dari pada media yang lainnya. Dalam pelaksanaannya, guru harus mampu mempersiapkan segala keperluan dalam percobaan tersebut termasuk alat dan bahan yang dipilih untuk digunakan. Melalui kegiatan ini, anak akan dapat mengembangkan kemampuan sains melalui proses mengamati, mengklasifikasi, memprediksi, mengukur, eksperimen, dan mengkomunikasikan mengenai benda yang larut dan tidak larut dalam air.

\section{Metode}

Penelitian ini dilakukan dengan menggunakan metode kuantitatif dengan jenis penelitian eksperimen. Desain penelitian eksperimen yang digunakan dalam penelitian ini yaitu pre experimental design dengan rancangan one group pretes-postest design, Adapun penelitian ini dapat digambarkan sebagai berikut:

\footnotetext{
\begin{tabular}{llll|}
${ }_{9} \mathrm{O}_{1}$ & $\mathbf{X}$ & $\mathbf{O}_{2}$ \\
${ }_{10}^{10}$ Yuliani Yuliants, Nurani Sujiono, Metode Pengembangan Kognitif (Jakarta: Universitas Terbuka, 2004)
\end{tabular}

11 Slamet Suyanto, Pengenalan Sains Untuk Anak TK Dengan Pendekatan "Open Inquiri”, http: journal Pengenalan Sains Untuk Anak TK_2.pdf, 2005 (online) diakses pada tanggal 20 Oktober 2013
} 
$\mathrm{O}_{1}=$ nilaipretest tentang pemahaman konsep sains sebelum diberikan treatment berupa penerapan model pembelajaran discovery.

$\mathrm{X}=$ pemberian treatment berupa penerapan model pembelajaran discovery

$\mathrm{O}_{2} \quad=$ nilai posttest tentang pemahaman konsep sains setelah diberikan treatment berupa penerapan model pembelajaran discovery.

$\mathrm{O}_{2}-\mathrm{O}_{1}=$ pengaruh penerapan model pembelajaran discovery terhadap kemampuan sains anak.

\section{Populasi, Sampel, dan Lokasi Penelitian}

1. Populasi

Populasi dari penelitian ini adalah anak kelompok B TK Tunas Harapan 1 Tunggunjagir tahun ajaran 2013/2014 yang berjumlah 14 anak, terdiri dari 4 anak laki-laki dan 10 anak perempuan.

2. Sampel

Sampel dalam penelitian ini adalah seluruh populasi yang berjumlah 14 anak, terdiri dari 4 anak laki-laki dan 10 anak perempuan.

3. Lokasi Penelitian

Penelitian ini dilakukan di TK Tunas Harapan 1 Tunggunjagir kecamatan Mantup kabupaten Lamongan.

\section{Instrumen Penelitian}

Instrumen penelitian merupakan alat yang digunakan oleh peneliti dalam mengumpulkan data agar pekerjaannya lebih mudah dan hasilnya lebih baik, dalam arti lebih cermat, lengkap, sistematis, sehingga mudah diolah. ${ }^{12}$ Dalam penelitian ini, pengembangan instrumen penelitian meliputi :

\section{Tabel 1. Intrumen Penelitian}

\footnotetext{
${ }^{12}$ Suharsimi Arikunto, Prosedur Penelitian (Suatu Pendekatan Praktik). (Jakarta : Rineka Cipta, 2010), 203
} 


\begin{tabular}{|c|c|c|c|c|}
\hline No & $\begin{array}{c}\text { Aspek yang } \\
\text { diamati }\end{array}$ & Indikator & Item & $\begin{array}{l}\text { No. } \\
\text { item }\end{array}$ \\
\hline 1. & Observasi & $\begin{array}{l}\text { Menyebutkan dan menceritakan } \\
\text { perbedaan dua buah benda }\end{array}$ & $\begin{array}{l}\text { Mampu menyebut- } \\
\text { kan ciri-ciri benda } \\
\text { yang ditunjuk guru }\end{array}$ & 1 \\
\hline 2. & Klasifikasi & $\begin{array}{l}\text { Mengelompokkan benda dengan } \\
\text { berbagai cara menurut ciri-ciri tertentu. } \\
\text { Misalnya : menurut warna, bentuk, } \\
\text { ukuran }\end{array}$ & $\begin{array}{l}\text { Mampu } \\
\text { mengelompokkan } \\
\text { benda yang larut dan } \\
\text { tidak larut dalam air }\end{array}$ & 2 \\
\hline 3 & Eksperimen & $\begin{array}{l}\text { Mencoba dan menceritakan tentang apa } \\
\text { yang terjadi jika warna dicampur, } \\
\text { benda-benda dimasukkan ke dalama air } \\
\text { (terapung, melayang, tenggelam), }\end{array}$ & $\begin{array}{l}\text { Mampu } \\
\text { mengelompokkan } \\
\text { benda yang larut dan } \\
\text { tidak larut dalam air }\end{array}$ & 3 \\
\hline 4 & Komunikasi & $\begin{array}{l}\text { proses pertumbuhan tanaman, benda- } \\
\text { benda dijatuhkan (gravitasi), benda } \\
\text { didekatkan dengan magnet, mengamati } \\
\text { benda dengan kaca pembesar, } \\
\text { merasakan dan membedakan macam- } \\
\text { macam rasa, mencium macam-macam } \\
\text { bau, mendengar macam-macam bunyi } \\
\text { dan hal-hal yang terjadi dalam aktifitas } \\
\text { eksperimen sederhana lainnya }\end{array}$ & $\begin{array}{l} \\
\text { Mampu mencoba } \\
\text { melapor-kan } \\
\text { kejadian dalam } \\
\text { percobaan benda } \\
\text { yang larut dan tidak } \\
\text { larut dalam air }\end{array}$ & 4 \\
\hline
\end{tabular}

Teknik pengumpulan data dalam penelitian ini menggunakan participant observation sehingga peneliti dapat terlibat dalam kegiatan sehari-hari orang yang diamati atau yang digunakan sebagai sumber data penelitian. Sambil melakukan pengamatan, peneliti ikut melakukan apa yang dikerjakan oleh sumber data, dan ikut merasakan suka dukanya. Melalui observasi partisipan ini, maka data yang diperoleh akan lebih lengkap, tajam, dan sampai mengetahui pada tingkat makna dari setiap perilaku yang nampak. Berdasarkan metode observasi yang digunakan untuk mengamati kemampuan sains anak kelompok B maka digunakan ketentuan penilaian sebagai berikut:

Tabel 2. Ketentuan Penilaian Lembar Observasi ${ }^{13}$

\begin{tabular}{|c|c|}
\hline Skor & Keterangan \\
\hline 1 & Kurang \\
\hline 2 & Cukup \\
\hline 3 & Baik \\
\hline 4 & Sangat Baik \\
\hline
\end{tabular}

Penelitian ini diuji validitasnya dengan construct validity (validitas konstruksi), dimana validitas konstruksi ini dapat digunakan pendapat dari ahli. Dalam hal ini setelah instrumen dikonstruksi tentang aspek-aspek yang akan diukur dengan berlandaskan teori tertentu, maka selanjutnya dikonsultasikan dengan ahli. Reliabilitasnya menggunakan jenis

\footnotetext{
${ }^{13}$ Sugiyono, Metode Penelitian Kuantitatif Kualitatif dan RD (Bandung: Alfabeta, 2011), 4.
} 
internal consistency yang dilakukan dengan pengamatan (observasi). Adapun hasil data yang diperoleh dari pengujian reliabilitas adalah:

Tabel 3. Kontigensi Kesepakatan

\begin{tabular}{|l|c|c|c|c|c|c|}
\hline & \multicolumn{5}{|c|}{ Pengamat II (Bu Aini) } & \multirow{2}{*}{ Jumlah } \\
\hline \multirow{3}{*}{$\begin{array}{l}\text { Pengamat I } \\
\text { (Bu Lis) }\end{array}$} & Skor & 1 & 2 & 4 & 4 & \\
\cline { 2 - 7 } & 1 & & & & & \\
\cline { 2 - 7 } & 2 & & & & & \\
\cline { 2 - 7 } & 3 & & & 4 & & 1 \\
\cline { 2 - 7 } & 4 & & & & $1,2,3$ & 3 \\
\hline \multicolumn{2}{|c|}{ Jumlah } & & & 1 & 3 & 4 \\
\hline
\end{tabular}

Dari data yang diperoleh di atas maka dapat disimpulkan instrumen yang digunakan merupakan instrumen yang reliabel atau ajeg terbukti dari hasil hitung koefisien bernilai 1 . Sehingga instrumen observasi kemampuan sains anak yang digunakan dalam penelitian ini reliabel untuk digunakan dalam penelitian dan tidak perlu dilakukan pengulangan.

\section{Hasil Dan Pembahasan}

Dalam penelitian ini data diuji dengan uji wilcoxon match pairs test, dalam pelaksanaan pengujian hipotesis dengan uji wilcoxon match pairs testakan digunakan tabel penolong. Data hasil sebelum perlakuan (pretest) dan sesudah perlakuan (posttest) seluruh anak dimasukkan kedalam tabel penolong untuk nencari beda antara sebelum perlakuan (pretest) dan sesudah perlakuan (posttest). berikut adalah hasil prestest-posttest yang nantinya dimasukkan ke dalam tabel penolong.

Data hasil pretest dan posttest tersebut kemudian dimasukkan dalam tabel penolong wilcoxon untuk dihitung uji beda dengan teknik wilcoxon match pairs test.

Tabel 4. Tabel Penolong Wilcoxon Match Pairs Test

\begin{tabular}{|c|c|c|c|c|c|c|c|}
\hline \multirow{2}{*}{ No } & \multirow{2}{*}{ Nama Subyek } & \multirow{2}{*}{$X_{1}$} & \multirow{2}{*}{$X_{2}$} & Beda & \multicolumn{3}{|c|}{ Tanda jenjang } \\
\hline & & & & $X_{2}-X_{1}$ & Jenjang & + & - \\
\hline 1 & JSC & 17 & 25 & 8 & 13,5 & $+13,5$ & - \\
\hline 2 & IFI & 23 & 30 & 7 & 11,5 & $+11,5$ & - \\
\hline 3 & SFN & 20 & 26 & 6 & 8 & +8 & - \\
\hline 4 & ALF & 26 & 31 & 5 & 2,5 & $+2,5$ & - \\
\hline 5 & AGG & 21 & 27 & 6 & 8 & +8 & - \\
\hline 6 & HNY & 21 & 26 & 5 & 2,5 & $+2,5$ & - \\
\hline 7 & DOI & 20 & 26 & 6 & 8 & +8 & - \\
\hline 8 & WCK & 21 & 27 & 6 & 8 & +8 & - \\
\hline No & Nama Subyek & $X_{1}$ & $X_{2}$ & Beda & $\begin{array}{c}\text { Tanda } \\
\text { jenjang }\end{array}$ & No & $\begin{array}{l}\text { Nama } \\
\text { Subyek }\end{array}$ \\
\hline 9 & NDA & 22 & 27 & 5 & 2,5 & $+2,5$ & - \\
\hline 10 & WHY & 20 & 25 & 5 & 2,5 & $+2,5$ & - \\
\hline
\end{tabular}




\begin{tabular}{|c|c|c|c|c|c|c|c|}
\hline 11 & AKA & 20 & 26 & 6 & 8 & +8 & - \\
\hline 2 & BBM & 25 & 29 & 4 & 1 & +1 & - \\
\hline 13 & RZA & 20 & 27 & 7 & 11,5 & $+11,5$ & - \\
\hline 14 & ANA & 15 & 23 & 8 & 13,5 & $+13,5$ & - \\
\hline \multicolumn{8}{|c|}{ Jumlah } \\
\hline
\end{tabular}

Berdasarkan perhitungan pada tabel di atas, untuk menguji signifikansi hubungan dengan menggunakan tabel penolong Wilcoxon untuk $\mathrm{N}=14$ dengan taraf signifikansi $5 \%$ maka $T_{\text {tabel }}=21$. Dari perhitungan di atas diketahui bahwa seluruh subyek penelitian ini tidak ada yang tidak berpengaruh, hasil dapat dilihat pada post-test, oleh karena itu nilai $\mathrm{T}_{\text {hitung }}$ yang diperoleh adalah 0 .

Jika $\mathrm{T}_{\text {hitung }} \leq \mathrm{T}_{\text {tabel }}$ maka Ho ditolak dan Ha diterima. Maka dari hasil perhitungan di atas diketahui bahwa $T_{\text {hitung }}=0$, sedangkan $T_{\text {tabel }}=21$ sehingga $T_{\text {hitung }} \leq T_{\text {tabel }}$ dan hipotesis penelitian diterima. Jadi dapat disimpulkan bahwa ada pengaruh penggunaan metode eksperimen terhadap kemampuan sains pada kelompok B di TK Tunas Harapan 1 Tunggunjagir kecamatan Mantup kabupaten Lamongan.

Dalam mengembangkan kemampuan sains anak usia dini, peneliti dan guru memberikan perlakuan dengan menerapkan metode eksperimen. Metode eksperimen ini dianggap tepat dan sesuai dengan karakteristik anak usia dini. Hal itu dibuktikan dengan adanya pemberian kesempatan pada anak usia dini untuk mengeksplorasi kemampuan sainsnya melalui kegiatan yang telah dipilih. Dengan melibatkan anak usia dini secara aktif dalam pembelajaran maka kemampuan, konsep yang dipelajari akan lebih bermakna.

Kegiatan yang dipilih sebagai sarana untuk mengembangkan kemampuan sains anak adalah kegiatan percobaan benda yang larut dan tidak larut dalam air. Bahan yang digunakan untuk percobaan larut dan tidak larut dalam air setiap harinya berbeda-beda. Treatment hari pertama menggunakan gula merah dan beras, treatment hari kedua menggunakan garam dan kerikil, treatment hari ketiga menggunakan gula pasir dan pasir, serta untuk treatment hari keempat menggunakan madu, teh, sirup, gula pasir. Hal ini bertujuan agar anak mengetahui berbagai macam benda beserta ciri-cirinya.

Pemberian perlakuan dilakukan berulang-ulang agar anak dapat memahami konsep sainsyang telah diberikan. Hal ini sesuai dengan hukum belajar yang dikemukakan oleh Thorndike yaitu hukum latihan (the law of exercise) dimana jika makin sering suatu pelajaran diulangi, makin dikuasailah pelajaran tersebut ${ }^{14}$.

Selama melakukan kegiatan percobaan benda larut dan tidak larut dalam air, anak menemukan berbagai pengetahuan baru. Selain mengenal berbagai macam benda beserta ciricirinya, anak juga mampu mengenal macam-macam rasa. Ketika anak mencoba melarutkan madu, gula, garam, sirup dan gula jawa dengan air, mereka merasa senang untuk mencicipi rasanya. Mereka merasa bangga karena yang mereka minum adalah buatan mereka sendiri. Dalam hal ini anak sudah mampu untuk mengkonstruksi pengetahuannya sendiri. Anak berinteraksi langsung dengan objek dan memperoleh pengetahuan dengan berbagai inderanya

14 Widya Wati. Makalah Strategi Pembelajaran Teori Belajar dan Pembelajaran, 2010, (online) http://widya57physicsedu.files.wordpress.com/2010/12/no-29-widya-wati-02-teori-belajar-dan-pembelajaran.pdf 
dari objek tersebut. Secara tidak langsung kegiatan ini sesuai dengan rambu-rambu kegiatan pembelajaran sains untuk anak TK yang dikemukakan oleh Suyanto. ${ }^{15}$

\section{Penutup}

Berdasarkan rumusan masalah maka dapat disimpulkan bahwa penggunaan metode eksperimen dapat diterapkan dan memiliki pengaruh yang signifikan terhadap kemampuan sains pada anak kelompok B TK Tunas Harapan 1 Tunggunjagir kecamatan Mantup kabupaten Lamongan.

Hal tersebut dapat diketahui dengan adanya peningkatan skor antara sebelum (pre-test) dan sesudah pemberian perlakuan (post-test), dengan hasil $\mathrm{T}_{\text {hitung }}=0$ dan $\mathrm{T}_{\text {tabel }}=21$ di mana $\mathrm{T}_{\text {hitung }} \leq \mathrm{T}_{\text {tabel }}$ sehinggaHo ditolak dan Ha diterima. Dengan demikian, hipotesis penelitian yang berbunyi "metode eksperimen mempunyai pengaruh yang signifikan terhadap kemampuan sains pada anak kelompok B di TK Tunas Haparan 1 Tunggunjagir, Lamongan" telah terbukti.

\section{Daftar Pustaka}

Arikunto, Suharsimi. Prosedur Penelitian (Suatu Pendekatan Praktik). Jakarta : Rineka Cipta, 2010.

Nugraha, Ali. Pengembangan Pembelajaran Sains Pada Anak Usia Dini. Jakarta: Depdiknas, 2005.

Sugiyono, Metode Penelitian Kuantitatif Kualitatif dan RD. Bandung: Alfabeta, 2011.

-------, Statistik Non Parametrik. Bandung: Alfabeta, 2012.

Sujiono, Yuliani Nurani. Metode Pengembangan Kognitif. Jakarta: Universitas Terbuka, 2004.

-------, Konsep Dasar Pendidikan Anak Usia Dini. Jakarta: Indeks, 2009.

Suyanto, Slamet. Pengenalan Sains Untuk Anak TK Dengan Pendekatan “Open Inquiri”. http: journal Pengenalan Sains Untuk Anak TK_2.pdf(online) 2003. diakses pada tanggal 20 Oktober

Wati, Widya. Makalah Strategi Pembelajaran Teori Belajar dan Pembelajaran(online) 2010.http://widya57physicsedu.files.wordpress.com/2010/12/no-29-widya-wati-02teori-belajar-dan-pembelajaran.pdf diakses pada 20 Oktober 2013.

Yulianti, Dwi. Bermain Sambil Belajar Sains di Taman Kanak-kanak. Jakarta: Indeks, 2010.

\footnotetext{
${ }^{15}$ Slamet Suyanto, Pengenalan Sains Untuk Anak TK Dengan Pendekatan “Open Inquiri”, 2005 (online) http: journal Pengenalan Sains untuk Anak TK_2.pdf, diakses pada tanggal 20 Oktober 2013
} 